Lamija M I L I Š I Ć (Filozofski fakultet Univerziteta u Sarajevu) lamce95@yahoo.de

\title{
JOYCEOV FINNEGANS WAKE I MCCARTHYJEV REMAINDER: KODIRANJE I JEZIČKO RASLOJAVANJE
}

Primljeno: 13. 9. 2018.

UDK: 821.111.09-31 Joyce, J.

821.111.09-31 McCarthy, T.

Cilj ovog rada jeste razmotriti pojmove kôd i jezičko raslojavanje u sklopu analize djela Finnegans Wake Jamesa Joycea i Remainder Toma McCarthyja. Kôd se definira kao prijelaz iz područja mimeze u područje smisla. Analiza polazi od propitivanja žanrovskog određenja djela Finnegans Wake i Remainder, kao i statusa književnih likova u njima. Dokazuje se kako književni likovi u ta dva djela posjeduju "retorički kodiran identitet" i razmatraju se metode kojima je taj identitet postignut te učinci tih metoda. Pokazuje se na koji način je tehnika brikolaža primijenjena u Joyceovom i McCarthyjevom slučaju - te se ta tehnika povezuje sa pojmom koda. U zaključnom dijelu rada objašnjava se način na koji Joyceov i McCarthyjev tekst koriste književni jezik radi autorefleksije koda kojim su napisani. Shodno tome, kôd ostaje unutar područja mimeze (i ne zalazi u područje smisla). $U$ radu se nudi teza o književnom jeziku kao performativu, čime se sugeriše promjena poimanja ontološkog statusa likova u književnom tekstu.

Ključne riječi: generativna fikcija, kôd, pamćenje, bricolage, performativ

\section{UVOD}

"Evo u čemu je stvar s romanom Finnegans Wake - Joyce je smatrao da je to posljednji roman, onaj u kom će sudbina književnosti spoznati samu sebe. (...) No pokušao sam dokazati, ranije, da je bio potpuno, podvlačim, potpuno u krivu - da je Finnegans Wake zapravo prva knjiga. Finnegans Wake je izvorni kôd romana."

Tom McCarthy, intervju za Believer (1. juna 2008)

U tekstu "Building and Disintegrating Stories" H. F. Gomes bavi se romanima nejasne, dezintegrisane strukture. Njima oponira tzv. romane fiksne strukture. Oni nastaju tako što autor formira mrežu označitelja koji, makar 
bili proizvoljni, grade strukturu romana, a ta struktura biva ograničena autorovom voljom. Čitaocu je, stoga, onemogućeno sudjelovanje u nastanku takve strukture. Kao primjer romana fiksne strukture Gomes navodi dva naslova J. Joycea: Uliks (1922) i Finnegans Wake (1939). Roman Uliks Gomes opisuje kao preuveličavanje nelinearnosti, koju na koncu kontroliše sam autor. S druge strane, romani poput Finnegans $W a k e^{1}$ podstiču čitaoca da osvijesti tekst kao fiksnu strukturu. Jedan od takvih romana je i prvijenac Toma McCarthyja Remainder (2005).

Glavni lik McCarthyjevog romana Remainder saopćava čitaocu da je prije nekog vremena doživio nesreću - dio metalne konstrukcije mu je sa stropa pao na glavu, zbog čega je izgubio pamćenje. U nastavku romana junak nastoji umjetno oživjeti memorijske slike koje mu sporadično dolaze u svijest. Tim slikama uskraćen je njihov izvorni kontekst, te je njihova reanimacija u stvarnosti (u sadašnjosti) podređena upravo junakovoj volji i fiksnoj strukturi. Ta fiksna struktura zastupljena je na dva nivoa. Prvi je nivo radnje samog romana - sva sjećanja inscenirana su u sadašnjosti po vrlo strogim junakovim uputama. Drugi nivo otkriva nam se sagledamo li roman s naratološkog aspekta, prosto rečeno, obratimo li pažnju na to da je glavni junak romana 52 ujedno i narator. Prva rečenica romana glasi: “O samoj nesreći mogu reći vrlo malo. Gotovo ništa. Nešto je padalo s neba. Tehnologija. Dijelovi, komadi. To je, zapravo, to: to je sve što mogu otkriti. Znam da nije mnogo" (prevela L. M.; McCarthy 2007: 2). ${ }^{2}$ Primijetimo da glavni lik/narator u biti govori da je ono što će nam ispričati na narednim stranicama o nesreći "sve što može otkriti” - dakle on ne govori da se ne sjeća šta se desilo prije nesreće,

${ }^{1}$ Napominjem da u radu koristim naslove obaju romana na engleskom jeziku. Sam Remainder nije preveden na naš jezik, a situacija sa Joyceovim djelom nešto je drugačija. Iako postoji prijevod Siniše Stojakovića (prijevod prve knjige romana), naslovljen Finegana budenje, odlučila sam da koristim izvorni naslov romana. Razlog tome tiče se, s jedne strane, pojma "wake" koji bi se mogao protumačiti kao "bdjenje", ali i "buđenje". S druge strane, sam naslov djela referenca je na irsku narodnu baladu; za sada samo želim spomenuti da se izraz "Finnegan" može dvojako tumačiti: kao izvjesni Tim Finnegan iz balade, ali i kao zajednička imenica "finnegan”, kao Joyceov naziv za Irca. Utoliko, kako Stojakovićev naslov glasi "Finegana buđenje", riječ "Finegan" u sebi uključuje oba značenja koja je Joyce mogao namijeniti naslovu svog djela. Referenca na baladu svakako opravdava Stojakovićev odabir pri prijevodu naslova, ali mislim da je za potrebe ovog rada pogodno ostaviti naslov u njegovom izvornom obliku, u biti zbog velike razlike između pojmova "bdjenje" i "buđenje" u našem jeziku te pojma "wake" koji značenja tih riječi u sebi objedinjuje.

${ }^{2}$ Izvorni tekst: "About the accident itself I can say very little. Almost nothing. It involved something falling from the sky. Technology. Parts, bits. That's it, really: all I can divulge. Not much, I know." 
on čak priznaje da to što nam može otkriti "nije mnogo". Čitaočev pogled na radnju romana ograničen je naratorovom tačkom gledišta. Upravo se u citiranoj rečenici, ali i u cijelom McCarthyjevom romanu, očituje ono što Gomes naziva "podsticanjem čitaoca da osvijesti tekst kao fiksnu strukturu". Pojam fiksne strukture uzimam u ovom radu kao temeljnu poveznicu dvaju književnih djela iz naslova - Finnegans Wake i Remainder - te će analiza koja slijedi istražiti konsekvence te fiksne strukture i uopće njene mogućnosti koje su Joyce i McCarthy iskoristili u svojim djelima.

Michael Riffaterre u tekstu "The Self-sufficient Text" određuje pojam koda kao verbalnu strukturu koja nema inherentno značenje, već služi kao leksikon i sadrži već gotove sintaksičke nizove za bilo koje značenje što ga iziskuje dati kontekst (Riffaterre 1973: 41). Taj pojam koda može se proširiti i pojmom bermeneuticki kôd, koji definira R. Barthes u djelu S/Z (Barthes 2002: 84-88). Hermeneutički kôd objedinjuje sve jedinice koje artikulišu pitanje, njegov odgovor, mogućnosti koje odlažu odgovor te mogućnosti koje konstituišu enigmu i dovode je do razrješenja. U kontekstu teksta Finnegans Wake enigma koju treba riješiti svakako je enigma da li je H. C. E. kriv za zločine za koje je optužen. U slučaju romana Remainder enigma se sastoji u tajni protagonistovog sjećanja, enigma je, konačno, u nesreći koja mu se desila.

Nadalje, u svom djelu Semiotics of Poetry Riffaterre objašnjava proces transkodiranja - proces u kom čitalac kao dekoder književnog teksta polazi od otkrivanja smisla teksta da bi došao do njegovog značenja. Otkriti smisao teksta predstavlja susret sa mimetičkim registrom tog teksta (Riffaterre 1978: 4-5). No, sami književni tekstovi "prijete" logici mimeze: svako naredno čitanje istog teksta otkriva niz odstupanja od početnog ustrojstva mimeze.

Riffaterre shvaća mimezu kao matricu teksta, koje čitalac postaje svjestan u ponovljenom čitanju, te mu tekst postaje jedinstven znak, hipogram, koji generira i matricu i sve njene devijacije. U tom trenutku čitalac otkriva značenje teksta. Dakle, transkodiranje je proces "što ga čitatelj provodi kad se premješta iz mimetičkog u smisaoni registar teksta odnosno kada prvo, heuristično značenje zamjenjuje drugim, hermeneutičnim čitanjem" (Biti 2000: 253-255).

Daljnja analiza u ovom radu podrazumijeva tu definiciju transkodiranja, s naglaskom na razlici između mimetičkog i smisaonog registra. Nastojat će se pokazati kako Joyce mimezu koristi umnožavanjem referenci gotovo svake pojedine riječi/fraze, ostvarujući pritom razne intertekstualne veze i istovremeno autorefererirajući na svoj tekst koji proizvodi te reference tako upadljivo. Umnožavanjem referenci udaljava se od smisaonog registra - i to čini Finnegans Wake teško čitljivim. 
Analiza Joyceovog i McCarthyjevog teksta također je usmjerena ka pojmu koda te teži objasniti McCarthyjevu izjavu da Finnegans Wake nije posljednji, nego prvi roman, da je on "izvorni kôd romana". Bitno je naglasiti da je težište analize na romanu Finnegans Wake te da se polazi od pretpostavke da je Remainder roman koji prati taj Joyceov "izvorni kôd romana".

\section{PAD ČOVJEKA U JEZIK}

\section{"THE NOVELISTIC FALLACY"}

Ovo poglavlje počinjem pitanjem: šta znači biti izvornim kodom romana? Djelomičan odgovor nudi autorica M. Norris u svom djelu The Decentered Universe of Finnegans Wake: Finnegans Wake nije roman. To je očito ako se krene od činjenice da Finnegans Wake autorefleksivno insistira na pripovijedanju o događajima putem jezika. Pažnja samog teksta potpuno je usmjerena na jezik kojim se pripovijeda i način na koji se pripovijeda, te se uslijed tog manira gubi jedna od ključnih odlika romana:

(...) romaneskna fabula, koja podrazumijeva prikaz pojedinčevog iskustva kao probnog tla stvarnosti i stoga opravdava istraživanje svakodnevnog života u književnosti. Finnegans Wake ne podržava te uslove romanesknog žanra i, doista, postoji mnogo dokaza koji potvrđuju da je to djelo napisano kako bi se suprotstavilo realističkoj epistemologiji što je dominirala prozom još od 18. vijeka. Narativna tehnika Finnegans Wake iskušava prioritet subjektivnog individualnog iskustva na nekoliko načina. Singularnost individualnog iskustva - njegova jedinstvenost - podriva se replikacijom događaja i nestabilnošću likova. Uobičajena povezanost događaja u romanesknom pripovijedanju zamijenjena je u Finnegans Wake slobodnim asocijacijama. (prevela L. M.; Norris 1976: 11)

Norris se poziva na djelo The Rise of the Novel (autor I. Watt), u kom se osnovom romana kao žanra smatra filozofija subjektivizma iz 18 . vijeka. $U$

${ }^{3}$ Izvorni tekst: “(...) the novelistic plot, which portrays the individual's experience as the testing ground of reality and thereby justifies the exploration of everyday life in literature. Finnegans Wake fails to support these novelistic premises and indeed, there is ample evidence to suggest that the work is designed precisely to refute the realist epistemology that has dominated prose fiction since the eighteenth century. The narrative tehnique of Finnegans Wake challenges the primacy of subjective individual experience in several ways. The singularity of individual experience - its uniqueness - is undermined by the prelication of events in novelistic narration is replaced in Finnegans Wake by contiguous associations on the order of psychoanaltic free associations." 
tom ključu individua se smatra sposobnom za autentičnu spoznaju svijeta, nezavisnu od kolektivnog pamćenja: "Književni tradicionalizam doveden je u pitanje zahvaljujući romanu, čiji je primarni kriterij istina individualnog iskustva - individualnog iskustva koje je uvijek jedinstveno i stoga novo" (prevela L. M.; Watt 2000: 22). ${ }^{4}$

Wattovo tumačenje romana sukladno je s tezom G. Lukácsa iznesenom u njegovoj Teoriji romana. Lukács navodi kako roman sadrži dva bitna elementa koja su međusobno zavisna: kontingentni svijet i problematični individuum. Bit vanjskog svijeta sastoji se u "jazu između zbilje i ideala". S druge strane, ta ista zbilja ništavna je bez imanentnog ideala. Prema tome, postoji neusklađenost unutarnjosti i njenog djelovanja te nesposobnost svijeta da se dovrši uslijed zastranjenja od ideje. Dakle, jaz između zbilje i ideala koji posjeduje jedna individua "zaključuje" se elementima svijeta koji imaju potrebu za sistemom ideja, ali ga ne mogu doseći. Prelaskom na temu unutarnje forme romana Lukács predstavlja roman kao putovanje problematičnog individuuma do samog sebe:

Istina, nakon dostizanja te samospoznaje pronadeni ideal osvjetljava imanentnost života kao svoj životni smisao, ali podvojenost između bitka i trebanja nije ukinuta, i to ne može biti u sferi romana. (...) Imanencija smisla kakvu zahtijeva forma data je njegovim doživljajem da je ovaj puki opažaj smisla najviše što mu je život mogao pružiti. (...) karakter ove biografske forme koja je orijentisana na ideje (...) (je) tipičan predstavnik onog sistema ideja i doživljenih ideala koji regulativno određuju i unutarnji i vanjski svijet romana. (Lukács 1990: 63-65)

Dakle, sam odnos individuuma i svijeta o kom Lukács govori počiva na odlici svijeta da je spoznatljiv, i upravo zbog sposobnosti individuuma da spoznaje svijet nastaje spomenuti jaz između zbilje i ideala. Ideali individuuma predstavljeni su kroz tekst specifičnim diskursom kojim se konstituiše (ili pak kog koristi) taj individuum, tj. taj književni lik.

Kada govorimo o autentičnom diskursu književnog lika, svakako to možemo povezati i sa djelom $M$. Bahtina $O$ romanu. Bahtinova teza ići će u prilog stavu da Finnegans Wake nije roman, posebno ako se obrati pažnja na to kako je Bahtin odredio bit romana: to su "čovjek koji govori i njegovo slovo" (Bahtin 1989: 93-130). Poznati su također njegovi pojmovi raznojezičje i raznorječje (Bahtin 1989: 30-58). Raznojezičje određuje roman kao polje

${ }^{4}$ Izvorni tekst: "This literary traditionalism was first and most fully challenged by the novel, whose primary criterion was truth to individual experience - individual experience which is always unique and therefore new." 
mnoštva jezika, utoliko ga Bahtin naziva "stilski prljavim". Već se u tom pojmu može vidjeti značaj spomenutog autentičnog diskursa pojedinih likova: čovjek koji govori uspostavlja razliku između sebe i društva upravo kroz vlastito slovo. Raznorječje se odnosi na činjenicu da se u romanu čovjekovo slovo doživljava kao iskaz pa su u romanu predstavljeni različiti govori/iskazi. U slučaju Joyceovog teksta riječ svakog pojedinog "lika" nije napisana da bi on bio konstituisan kao "čovjek koji govori" - niti su dijalozi otvorene razmjene iskaza. Joyceov tekst ne dopušta "likovima" da iskažu svoje ideje/ideale vlastitim govorom jer je njihova riječ puna ranije spomenutih referenci koje se umnožavaju i stoga se iz napola izgrađenog konteksta u koji bi ih lik stavio vraćaju svojoj denotaciji. Taj povratak denotaciji povratak je riječi samog teksta kao cjeline, a ne "čovjeku koji govori" niti specifično njegovom slovu.

Norris primjećuje i to da se neka tema/motiv u Finnegans Wake ne prikazuje kroz pojedinačni događaj, kroz specifično iskustvo pojedinih likova, niti se taj motiv realizuje kroz direktan, pojedinačan iskaz (tj. pojedinačan, istaknut diskurs). Tome se može dodati da čak i ako je fokalizacija u vlasništvu nekog lika, njegova/njena subjektivna spoznaja zatomljena je manirom pripovijedanja, načinom upotrebe jezika, te ta jezička igra vrši enkripciju subjektivne perspektive i zadobija intrinzičnu vrijednost. Štaviše, ta jezička igra onemogućava književnom liku da uopće bude književni lik. On postaje, za sada se može grubo upotrijebiti sintagma, jezička instanca koja nas površnim konvencijama podsjeća na književni lik. Mi mislimo da je pred nama enkripcija subjektivnosti tog lika, no to je zapravo enkripcija samog jezika. Utoliko Norris govori o "antisubjektivizmu" koji Finnegans Wake baštini. Svoj stav Norris dalje dokazuje usporedbom Joyceovih djela Portret umjetnika u mladosti i Finnegans Wake, ali ja bih na ovom mjestu ponudila nešto drugačiji primjer, koji ipak ističe ranije spomenuti odnos fokalizacije i pripovjedne jezičke igre. Radi se o sedmom poglavlju prve knjige, o sceni u kojoj Shaun opisuje Shemov navodno gnusni čin na latinskom jeziku. Iz Shaunove tačke gledišta promatramo Shema koji od svog urina pravi tintu i njome ispisuje cijelo svoje tijelo. Međutim, Shaun odlučuje ispripovijedati priču na latinskom jeziku da s tim gnusnim činom ne bi morao suočiti širu masu (koja ne zna latinski), a da bi one koji ipak znaju latinski poštedio sramote i prikrio proste riječi milozvučnim latinizmima:

Vi se pitate, pička mu lepa materina, kako? Nek manir i materija toga za ova naša sportska vremena bude ogrnuta jezikom zacrvenelih porporata tako da anglikanski original, zanemarujući njegovo grubo dunstersko izražavanje, može uvek da gleda žig skarleti na čelu drolje Vavilonske a da i ne oseti rumenilo na svom prokletom obrazu. 
Primum opifex, altus prosator, ad terram viviparam et cuncti-potentem sine ullo pudore nec venia, suscepto pluviali atque discinctis perizomatis, natibus nudis uti nati fuissent, sese adpropinquans, flens et gemens, in manum suam evacuavit (bighly prosy, crap in his hand, sorry!), postea, animale nigro exoneratus (...) (Džojs 2014: 188)

Iz tog citata može se zaključiti sljedeće: Shaun naglašava svoju perspektivu i iskorištava situaciju u kojoj mu je data fokalizacija kako bi na latinskom ispripovijedao priču o sramoti svog brata Shema. Međutim, Shaun i Shem su u Finnegans Wake, kao i svi ostali "likovi”, utjelovljenja određenih književnih arhetipa, dakle instance načela naglašene jezičkom igrom. Citat je poslužio da se istakne podređenost ličnog iskustva likova načinu na koji se pripovijeda o tom ličnom iskustvu, tj. uopće podređenost likova i motiva općoj autorefleksiji teksta Finnegans Wake. Bitno je da način na koji se pripovijeda ne pridonosi toliko dočaravanju ličnog iskustva lika koji pripovijeda - taj način nije lični diskurs tog lika niti pridonosi njegovoj karakterizaciji, on pridonosi "karakterizaciji” cjelokupnog teksta Finnegans Wake.

Književni lik u romanu inače simulira (ako već ne referira) neku ličnost; naglasak se stavlja na jedinstvenost svjetonazora te ličnosti, a jezik pritom služi da ta simulacija bude što uspješnija. U slučaju Finnegans Wake tekst neprestano vrši autorefleksiju, tako da jezik više ne služi simulaciji vanjezičke stvarnosti, već neprestano pada u svoje jezičke igre. Utoliko književni lik, kao proizvod simuliranja čovjeka od strane jezika, ne može nastati. Finnegans Wake nije čak ni tekst koji uživa u intertekstualnim vezama - njegovi "likovi" ne simuliraju ni likove iz drugih književnih djela; njegovi likovi, čini se, nastoje iscrpiti sve svoje intertekstualne i referencijalne potencijale kako bi takve veze banalizovali, kako bi se oslobodili prijetvornosti simulacije.

Protagonist romana Remainder dijeli ključnu sličnost sa likovima Finnegans Wake - i on je lišen spomenutog individualnog iskustva svijeta, zbog čega bi se i Remainder mogao nazvati "antisubjektivnim". Narator na početku romana kaže: "Ko može tvrditi da su ovo stvarna sjećanja?" Čitalac pred sobom ima književni lik lišen sjećanja, koji sa likovima u Finnegans Wake dijeli prazninu identiteta. McCarthyjev protagonist se na vrlo specifičan način odnosi prema svojoj "amneziji”:

"Upravo tako”, (Samuels) reče. "Čitanjem tih knjiga mi je odjednom pružen uvid u vlastitu prošlost. U njeno razumijevanje. Ako ne želiš ponavljati stvari, moraš ih razumjeti."

Pomno sam razmislio o tom što je Samuels rekao, te mu odvratih: "Ali ja želim ponavljati stvari." 
"Tako mi je Nazrul i rekao", odgovori Samuels. "On kaže..."

"I ja ih ne želim razumjeti." (prevela L. M.; McCarthy 2007: 132)

McCarthyjev protagonist upravo odbacuje sjećanje u korist koda i nastoji ostati vječno u toj enkripciji.

\section{KO ĆE BITI GOSPODAR?}

Jedan od ključnih motiva koji povezuju Finnegans Wake i Remainder jeste motiv pada. Remainder započinje, barem ako događaje složimo u fabulu, upravo padom metalne konstrukcije na glavu protagoniste koji zbog toga gubi pamćenje.

Navodim nekoliko primjera u kojima Joyce uspostavlja intertekstualnu vezu sa likom Humptyja Dumptyja i njegovim slavnim padom:

- "Veliki pad zida jajeta povuče za sobom u tako kratkom roku pfujd Finengana, inače solidnog čoveka, da njegova brdovita hamti glava odmah odasla jedan upitnik dobrano na zapad u potragu za njegovim damti nožnim prstima (...)" (Džojs 2014: 5-6)

- "Pa čak i da se Hamti ponovo stropošta damti puta tako nezgrapno u bradosalemu svih naših grandioznih razočarenja čekaće ga jaja na oko za doručak izjutra, sunčana strana pažljivo odozgo.” (Džojs 2014: 14)

Oba primjera pojavljuju se u prvom poglavlju prve knjige, koje govori o posrnulom H. C. E. Pad Humptyja Dumptyja se nešto kasnije u knjizi (sedmo poglavlje) povezuje sa padom Adama i Eve. Ovaj navod kao i prethodna dva svakako ima komičan efekt i mislim da to nije suvišno spomenuti:

- "Slomljena Jaja će pratiti ogrizine Jabuka jer gde postoji Volja tu je i njegov Zid.” (Džojs 2014: 177)

Paralelno s tom vezom, značajno je što se motiv pada u Finnegans Wake uvijek povezuje s likom H. C. E. Pad je njegov lično, ukoliko se osvrnemo na blud za koji je optužen. Međutim, pad se istovremeno tematizira kroz biblijski kontekst. Utoliko se fokus sa H. C. E., kao lika čovjeka na čijem smo pogrebu bili u prvom poglavlju prve knjige, prebacuje na opću ideju

${ }^{5}$ Izvorni tekst: "'Exactly', he said. 'Reading these was like suddenly being given the key to my own past. Understanding it. If you don't want to repeat things, you have to understand them.' / I thought about what Samuels had just said, then told him: / 'But I do wnat to repeat things.' / 'So Nazrul's informed me', Samuels answered. 'He says...' / 'And I don't want to understand them."” 
čovjeka kao posrnulog božjeg stvorenja. Shodno tome, jedinstvenost književnog lika okopnjuje. Naravno, to je slučaj i u mnogim drugim tekstovima, no specifičnost Joyceovog teksta je u tome što to okopnjavanje, taj proces apstrahiranja kojim se napušta partikularno u korist prepoznavanja univerzalnog, vrši sam tekst, a ne čitalac. Dakle, tekst ne pruža iluziju književnog lika kao jezičkog jedinjenja koje bi trebalo sličiti ljudskoj ličnosti pa da daje čitaocu mogućnost da iz tog konkretnog lika izvlači općenite zaključke.

Finnegans Wake ponavlja motiv pada i to eksplicitno ukazivanje na vlastiti podtekst (kakvo je treće poglavlje Knjige Postanka) daje tom podtekstu potpuno nov status. Tome u prilog ide i to da se Humpty Dumpty svaki put pojavljuje potpuno izvan konteksta tekuće scene. Dakle, očite reference na podtekst radnje nisu kodirane $\mathrm{u}$ tekst tako da budu neprimjetne i da ne narušavaju kontinuitet radnje - upravo suprotno.

Razmotrimo i intertekstualnu vezu "lika" Humptyja Dumptyja koji se pojavljuje u djelima Finnegans Wake i Alisa sa druge strane ogledala. Prisjetimo se ovog dijela:

- Kada ja upotrebim jednu reč - rekao je Jajčić Ovalčić nadmeno - onda ona znači baš ono što ja izaberem i ništa drugo.

- Problem je u tome - reče Alisa - da li si ti uopšte u stanju da izmišljaš reči sa mnogo značenja.

- Problem je jedino u tome - upleo se Jajčić Ovalčić - koja od njib treba da postane gospodar. Eto toliko! (naglasila L. M.; Kerol 2016: 179)

U odnosu kodirani tekst - izvorni tekst gospodar je svakako izvorni tekst. No, da li je to slučaj sa Finnegans Wake? Cijela dosadašnja analiza podudara se sa mojom početnom hipotezom: Finnegans Wake postavlja pitanje o mogućnosti koda uopće i time ga (na vrijednosnoj skali) stavlja u ravan $\mathrm{s}$ izvornim tekstom, ako ne i malo iznad njega.

D. Slote u tekstu "Did God Be Come?": The Definitive Exgenesis of HCE spominje Joyceovu bilješku: "5 min izloženosti / na oči cijelog svijeta". Nju tumači u kontekstu Joyceovog teksta kao enkripcije: "Kôd je razumljiv, ali samo kao najveća tajna; slika je vidljiva isključivo kao nerazrješiv (engl. overdetermined) kôd." Dakle, bit je u vidljivosti, u izloženosti koda. Stoga Slote zaključuje kako Bdjenje nije sjećanje na Pad, već je šifrirano kao Pad. Dakle, na mjesto sjećanja u tekstu Finnegans Wake stavljen je kôd. Nadalje, identitet H. C. E. dat je kao povlačenje retoricki kodiranog identiteta (taj retorički kodirani identitet je "jezička instanca" koju sam ranije spominjala). 
H. Burrell u tekstu Narrative Design in Finnegans Wake primjećuje četiri vrste sredstava koja Joyce koristi: arhaizmi, strane riječi preko kojih uspostavlja vezu sa Biblijom (jer i u biblijskom tekstu nalazimo slične igre riječima), nedostatak navodnika (tj. instanca naratora i drugih pripovjedača/govornika u tekstu nije eksplicitna) i tzv. networking.

Networking je pojam koji povezuje Finnegans Wake i Remainder. Njime Burrell definira proces "opetovane upotrebe određenih kategorija riječi kako bi se u čitaočevu umu isprovocirala jedna od tema djela". Tako npr. svaki opis hranjenja u Finnegans Wake aludira na Adama i jabuku; te svaka scena silovanja ili uopće seksualnog odnosa aludira na izgnanstvo iz Raja, na čovjekov Pad. Utoliko se tema Pada ponavlja kroz Joyceov tekst putem raznih priča, i to je manir istovjetan onom u 1001 noći, koji s Finnegans Wake tako dijeli i odliku cirkularnosti radnje. Burrell primjećuje da ta cirkularnost opstoji istovremeno sa progresijom teksta i upućuje na tekst S. Becketta "Dante... Bruno. Vico.. Joyce" (Beckett i dr. 1929: 5-14). U tom tekstu Beckett u Finnegans Wake prepoznaje aluzije na filozofiju Giambattista Vica, koji je predložio cirkularnu viziju historije, koju Joyce primjenjuje u svoje četiri knjige Finnegans Wake. Prva je knjiga religijska (teokratska) faza, koja počinje sa gromom (Beckett je naziva Rođenje); druga je knjiga ljubavna dječja igra, Beckett je zove Brak (Vicova herojska faza); treća knjiga prolazi u snu, stoga odgovara Pogrebu ili Vicovoj ljudskoj fazi; četvrta knjiga završava zorom, stoga je opet prijelaz iz ljudske u teokratsku fazu.

Konačno se posvećujem tekstu Remainder. Prisjetimo se kako protagonist opisuje nesreću: "Nešto je padalo s neba. Tehnologija. Dijelovi, komadi." Taj niz rečenica nalazi se na prvoj stranici romana. Pogledajmo sada šta se dešava na samom kraju: protagonist se nalazi u avionu, bježeći od ljudi koji ga progone. Odjednom dobija ideju da uopće ne bježi, te naređuje pilotu da okrene avion, i tako u krug, do u beskonačnost. Javlja mu se misao o tragu koji avion ostavlja za sobom: to bi bila osmica, znak beskonačnosti - savršen samo da nema onog početnog traga uzlijetanja. Taj trag protagonist opisuje kao "otpadak", "ostatak" (engl. remainder).

$\mathrm{U}$ tom dijelu romana objašnjava se i sam naslov - remainder je shvaćen kao dio znaka beskonačnosti gdje je započeta njegova naizgled vječna putanja, koja se širi beskonačno u prošlost i budućnost. "Remainder" je ostatak, odbačen da bi znak poprimio svoje značenje. I tako se stiče cirkularnost uopće i tako McCarthyjev protagonist dostiže savršenstvo. Vratimo se na rečenice: "Nešto je padalo s neba. Tehnologija. Dijelovi, komadi." To bi svakako mogao biti opis pada dijelova aviona na tlo. Cirkularnost očita na 
kraju teksta omogućava motivu pada da postane osnova strukture tog teksta. Opetovanje scene Pada, naravno, susrećemo i u Finnegans Wake.

Pad nije zastupljen samo na početku i kraju romana Remainder. S. Miller u tekstu "Intentional Fallacies: (Re)enacting the Accidental in Tom McCarthy's 'Remainder”' (Miller 2015: 634-659) također primjećuje kako je narator kroz cijeli roman okupiran stvarima koje padaju. Takav je primjer sa crnim mačkama: nakon što je kupio Madlyn Mansions, protagonist kroz prozor iznad stepeništa promatra krov susjedne, niže zgrade i traži da se kupi nekoliko crnih mačaka koje će hodati/ležati na krovu. Nakon što mačke padnu s krova, on jednostavno traži da se donesu nove mačke.

$\mathrm{Na}$ koncu ovog poglavlja uvedimo i pojam bricolage C. Levi-Straussa. Na njega upućuje Norris u tekstu The Decentered Universe of Finnegans Wake (Norris 1976: 130-140). Pomoću brikolaža "struktura komunicira nezavisno od sadržaja” i to je, zapravo, definicija koda. Učinak brikolaža je da čitatelja nanovo nauči čitati. U Finnegans Wake pismo ALP, koje je ključ razrješenja enigme o zločinu za koji je optužen HCE, u jednom je trenutku romana na sitne dijelove pocijepala kokoš. Tako pismo ALP, u svojoj fragmentarnoj formi, postaje nova struktura, nezavisna od sadržaja koji je trebao razriješiti enigmu. Remainder nešto eksplicitnije komunicira sa pojmom fragmenta pa se opet vraćam na rečenicu: "Nešto je padalo s neba. Tehnologija. Dijelovi, komadi." Sve ono za čim traga McCarthyjev protagonist jeste upravo struktura koja komunicira nezavisno od sadržaja - taj sadržaj bi bilo njegovo sjećanje u koje on, vrlo odlučno, ne želi zalaziti.

\section{SIMULIRANJE PRAZNINE}

\section{JOYCEOVE SKRAĆENICE}

Prisjetimo se Sloteove opaske da Finnegans Wake nije sjećanje na Pad, već da je taj tekst šifriran kao Pad. Ključ te distinkcije možda se krije u načinu na koji Joyce gradi svoje književne likove. Naime, i HCE i ALP i njihova djeca lišeni su dimenzije ličnog iskustva. O tome je bilo riječi još na početku rada: čak i ako je Shaunu dana fokalizacija u trenutku kad opisuje Shemov gnusni čin, njegova "lična" perspektiva zapravo se sastoji od diskursa kojim se koristi, ali taj diskurs pritom nije njegov lični izričaj, taj diskurs ne produbljuje njegov lik, već je samom sebi svrha. Drugim riječima, na djelu imamo slučaj slobodnog neupravnog govora. 
Utoliko, Joyce svako naratološko sredstvo koje se inače koristi za karakterizaciju lika (ime, fizički opis, specifičan diskurs) svodi na specifičnost jezika i jezičke igre kojima se uopće daje liku ime, kojima se liku gradi njegov diskurs. To je već ranije spomenuti postupak brikolaža - strukture koja funkcionira nezavisno od sadržaja. Jednostavno rečeno: postoje određene jezičke strukture koje čine cjelinu što je nazivamo "književni lik"; u slučaju Finnegans Wake te strukture neprestano referiraju na same sebe, tako da prazne formalno uspostavljeni "književni lik" od eventualnog sadržaja.

$\mathrm{Na}$ taj način, svaka jezička struktura koja bi inače funkcionirala kao lični govor lika ne odražava njegovo iskustvo ni perspektivu na stvari, već predstavlja jezičku igru u nastanku. Referentna moć takvog jezika koristi se na dva plana: govor lika referira na svoj sadržaj, ali je također struktuiran po principu brikolaža. Utoliko, struktura vrši autoreferenciju. Navedimo konkretan primjer: osmo poglavlje prve knjige, u kom dvije pralje pripovijedaju o životu ALP. Taj primjer pokazuje jedan od načina realizacije brikolaža u Finnegans Wake: "Jošjoš! Jošjoš! Kaži mi još. Ispričaj mi sve do tančina. Hoću da znam svaku svakcatu sitnicu. Sve do onoga kako se desilo da na vrbi rodi grožđe" (naglasila L. M.; Džojs 2014: 203). Naglašena fraza (na engleskom 62 bi glasila "when pigs fly", u ovom slučaju "the potters fly into jagsthole") spominje se ranije u tekstu, u sedmom poglavlju. Ovaj put tu frazu izgovara Shaun. Dakle, kada pralja želi znati "kako se desilo da na vrbi rodi grožde", ona direktno referira na kontekst u kom je koristi Shaun. Praljin diskurs preuzima kontekst Shaunovog diskursa. Iz citata će biti jasno da ona nije bila prisutna u času u kom je izgovorena dotična fraza:

(...) mladi Master Šemi na svom prvom prapočetnom nastupu u sam cik protoistorije videvši sebe takvog i takvog, dok se zevzečio sa čičcima u njihovom rasadničkom zabavištu (...) izdiktirao svim svojim malim bracama i sestričicama prvu zagonetku univerzuma: upitavši, kada čovek nije čovek? (...) Jedno reče kada se nebesa tresu, drugo reče kad Bohemijske usne, treće reče kada on, ne, kada priskoči na časak, kada je gnostik i rešen da (...) jedno od najumnijih reče, kad on jede jabluku pa mu zmija zbiči žaoku, još jedno reče kada si star i sed i pun sna (...) i jedno kad na vrbi rodi grožđe. Svi su se izlupetali, tako da Šem lično, doktator, ponese šnjur, pravo rešenje bejavši - svi se predaju? - kada je on - s vama u sve dane do rascepa stena, - Sam. (Džojs 2014: 171-172)

Dakle, ovdje imamo slučaj u kom jedan književni lik (pralja) referira na govor drugog književnog lika (Shaun), i to sintagmom koja funkcionira kao općepoznata fraza (prvo kontekst) i kao odgovor na pitanje (kad čovjek nije čovjek?) - a tim se pitanjem ponovno uspostavljaju networking i tema Knjige 
Postanka. Tehnikom slobodnog neupravnog govora pralji se pripisuju riječi o događaju koji ona nikako ne može imati u sjećanju - time se potvrđuje Sloteova teza o Bdjenju kao šifriranom Padu, a ne sjećanju na Pad.

J. McCreedy u tekstu Narrating Sigla tumači skraćenice koje je Joyce dao svojim likovima i donosi sljedeću sliku (Hayman 1963: 50):

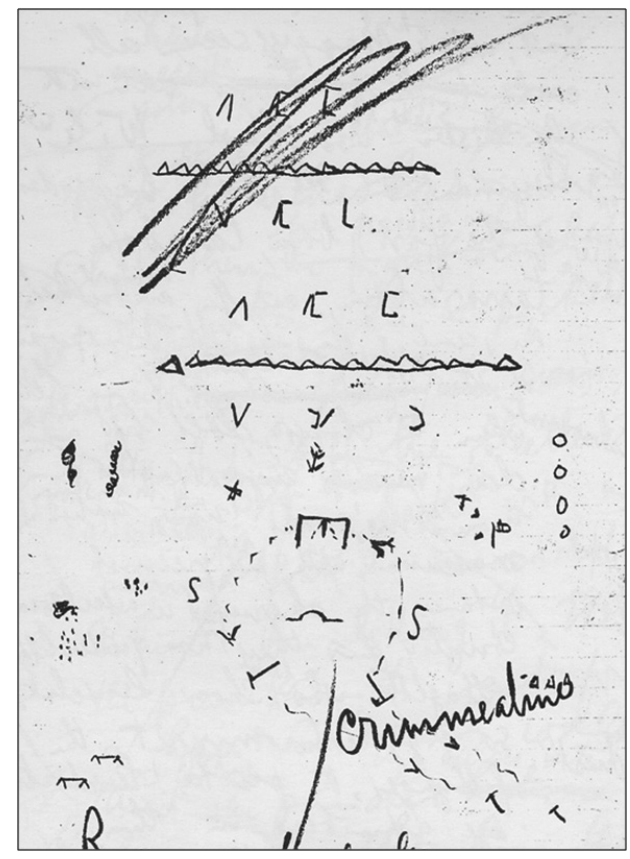

Na slici je Haymanovo tumačenje Joyceovih bilješki, tačnije onoga što je Joyce nazvao Battle Diagram. Skraćenice za likove su sljedeće:

Willingdone (HCE): $\Pi$; The Jinnies (Issy): $\checkmark$ i $\searrow$; The Lipoleums (tri odrasla sina): $\wedge$ (Shaun), $\Lambda$ (Shem) i $\sqsubset$ (Shaun - Shem) i Anna Livia Plurabelle: $\triangle$.

ALP se na dijagramu pojavljuje i kao " $\Delta \Delta \Delta \Delta \Delta \Delta$ ", što prema McCreedyju sliči na Alpe (stoga "ALP") te na krinolinu i rijeku (rijeku Liffey) u koje se ALP transformira tokom radnje teksta. Vidimo da se i na primjeru tih skraćenica Joyce poigrava referiranjem na likove i stoga iskorištava jezik i na ikoničkom planu: trokutasto uređene rečenice na početku sedmog poglavlja sadržajno govore (referiraju) na ALP, ali i način na koji su vizualno poredane referira na ALP (" $\triangle$ "). Također, "ALP" inicijali su Anne Livije Plurabelle, ali su i "ALPe" u koje se ona "transformira". "Ona" u tom slučaju 
u biti funkcionira kao "jezička instanca", ALP postaje šifrirani identitet koji se putem sličnosti s onim što kodira transformira baš u to. ALP, dakle, nije književni lik u "tradicionalnom" smislu simuliranja ljudskog bića - on simulira prazno ljudsko biće. Pod simulacijom praznine podrazumijevam da su Joyceovi likovi, kako je pokazano u ovom poglavlju, lišeni autentične tačke gledišta i, još važnije, lišeni sjećanja (ispražnjeni od sjećanja). Njihov govor nikada nije slobodan od šireg konteksta u kom se pojavljuje i upravo to denotiranje riječi koje likovi koriste u određenom kontekstu služi tome da se riječi povežu u novi kontekst, u kontekst samog teksta Finnegans Wake, možda u sjećanje samog teksta, a nikako pojedinačnog lika. Drugim riječima, ako jedna pralja od druge traži da joj kaže "kako je došlo do toga da na vrbi rodi grožđe", pralja koja govori o tom događaju zapravo ne govori o ličnim sjećanjima, jer događaj "kad na vrbi rodi grožđe" referira na Shaunov govor kom pralja nije mogla svjedočiti (ali mu je svjedočio sam tekst Finnegans Wake).

Tu lišenost sjećanja McCarthy koristi na nešto očitiji način - njegov protagonist preuzima ulogu naratora i kontrolira tekst utoliko što je njegova autentična tačka gledišta lišena sjećanja i uopće prikupljanja informacija koje

64 bi se asocijativno povezivale u iskustvo i sjećanje. On izričito govori kako želi "ponavljati, a ne razumjeti”. On jeste književni lik zato što zadržava autentičan diskurs, ali šta čitalac zna o njemu? Ne mnogo. Ipak, on se ostvaruje kao književni lik i mislim da je to stoga što nema razlike između njega kao naratora teksta i samog teksta. U Finnegans Wake "kad na vrbi rodi grožđe" fraza je kojom tekst komentariše sam sebe, a stvara privid da je ta fraza dio autentičnog diskursa likova. U romanu Remainder zadržana je ta autentičnost i stoga je ispražnjenost lika od sjećanja "nadoknađena" njegovom aktivnom ulogom naratora.

\section{DOSLOVNOST SNA}

Temu ispražnjenosti likova u djelima Finnegans Wake i Remainder moguce je proširiti tzv. tipografskim znakovima i fluidnim kretnjama slojeva značenja teksta - tim terminima autorica L. Boldrini opisuje Finnegans Wake u tekstu "Let Dante Be Silent". Boldrini povezuje Finnegans Wake sa Danteovom teorijom o polisemiji pozivajući se na autore koji su ranije uspostavili tu poveznicu, konkretno na S. Becketta (u već spomenutom tekstu "Dante... Bruno. Vico.. Joyce") te L. Guilleta (Claybook for Fames Foyce).

Danteova teorija o polisemiji ima dvije verzije. Za sada nam je bitna ona iz djela Convivio, gdje Dante navodi četiri sloja značenja: doslovni/historijski 
(površinski sloj teksta, njegov sadržaj/fabula; u tom sloju sadržani su svi ostali), alegorijski (skriveno, ali istinosno značenje), moralni/tropologijski (pouka teksta) i anagogijski (anagogical, sovravenso = "nadčulni", dakle apstrakcija od čulne, očite razine značenja).

Boldrini nadalje objašnjava kako H. Levin (Fames foyce: A Critical Introduction) primjenjuje tu Danteovu teoriju na Finnegans Wake:

Anagogijski, [Finnegans Wake] predviđa ni manje ni više nego razvoj civilizacije, suglasan sa Vicovim koncepcijama. Alegorijski, on slavi topografiju te atmosferu i okruženje Dublina. Doslovno, on bilježi nezgode - štaviše, noćne more - H. C. Earwickera dok on, njegova žena i troje djece spavaju u krevetima iznad puba, a nemirni san ponavlja jučerašnje događaje. Moralno, on objedinjuje sve te simbole u centralnu, miltonovsku temu - problem zla, izvorni grijeh. (prevela L. M.; cit. prema Boldrini 2002: 196) ${ }^{6}$

Doslovni sloj Finnegans Wake on pronalazi u snovima likova - Boldrini tu upućuje na Beckettovu izjavu da Joyce ne piše djelo o snu, već piše sam san, dodajući: “(...) [Joyce] je htio napisati sam san (...), 'jezikom snova', uvući citaoca izravno u snivačev um, neovisno o identitetu snivača" (prevela i naglasila L. M.; Boldrini 2002: 199). ${ }^{7}$ Pisanje nije shvaćeno kao priča o nečemu, već je ono to nešto. Ovdje se i Levin osvrće na autorefleksivnu moć Joyceovog teksta: pisanje je priča o pisanju. Tom bih dodala da je to pisanje zapravo proces konstituisanja književnog jezika kao koda, ali čini se da u Joyceovom slučaju književni jezik koristi mimetičku moć kako bi podražavao svijet sna i ostale tekstove u raznim intertekstualnim vezama, ali on istovremeno iz tog mimetičkog registra ne dospijeva do smisaonog registra, štaviše, uopće mu ne teži. Joyceov tekst je kôd koji, umjesto da svojom formom korespondira s kontekstom teksta/podražavanog svijeta koji bi trebao kodirati, neprestano izlazi iz tog konteksta, uvlači svoje riječi u konotacije i denotacije naizmjenično kako bi došao do konačnog, jedinog u potpunosti postojanog konteksta: to je kontekst samog teksta Finnegans Wake kao takvog. Stoga,

${ }^{6}$ Izvorni tekst: "Anagogically, it envisages nothing less than the development of civilization, according to Vico's conceptions. Allegorically, it celebrates the topography and the atmosphere of the city of Dublin and its environs. Literally, it records the misadventure - or rather the nightmares - of H. C. Earwicker, as he and his wife and three children lie in their beds above his pub, and broken slumber reiterates the events of the day before. Morally, it fuses all these symbols into a central theme, which is incidentally Milton's - the problem of evil, of original sin.”

${ }^{7}$ Izvorni tekst: “(...) he wanted to write the dream itself ('Joyce's] writing is not about something; it is that something itself"), in 'dream language', to plunge that is the reader directly into the dreamer's mind, regardless of the identity of the dreamer." 
kad Beckett kaže da Joyce ne piše djelo o snu, već sam san, to znači da sam tekst Finnegans Wake dijeli sa svojim sadržajem isti kontekst.

Sličan je slučaj i u McCarthyjevom Remainderu. Spomenuto "uvlačenje čitaoca izravno u snivačev um, neovisno o identitetu snivača" izravno je prikazano u tom romanu: protagonist ostaje anoniman do svršetka romana, a svaka inscenacija fragmenata njegovog sjećanja trebala bi služiti kao portal u "snivačev um", tj. u um čovjeka s amnezijom, kao portal u zaborav, jednako fragmentiran. No, kao što je objašnjeno ranije, McCarthyjev tekst čitljiviji je od Joyceovog zbog "autoritativne" instance naratora koji upravlja pričom te racionalizira svaku inscenaciju sjećanja, vraćajući je iz fragmentirane konotacije u denotaciju. Tu instancu naratora nalazimo i u Finnegans Wake, ostvarenu slobodnim neupravnim govorom.

Alegorijski sloj Finnegans Wake Levin pronalazi u topografiji i atmosferi grada Dublina. Boldrini smatra da su ti elementi svakako dijelovi Earwickerovog sna, stoga se trebaju vidjeti kao fizički kontekst njegovog sna, kao tragovi doslovnog sloja koji sadrži i druga, alegorijska značenja. U romanu Remainder fizički kontekst fragmenata sjećanja glavnog lika gradi se potragom, unutar fizičkog svijeta, za objektima/stvarima koje junak ima 66 u sjećanju. Tu se ističe vila Madlyn Mansions, doslovno kao nekretnina koju junak uzima u zakup, no i njen naziv kao alegorija za njegov zaborav, intertekstualna veza sa Proustovim keksima madeleine.

U nastavku svog teksta Boldrini se bavi načinom na koji Joyce referira na svoje "likove". Polisemija se, prema Boldrini, u Finnegans Wake ostvaruje tako što se prisutnost "lika" označava pojavom tipografskih znakova/karaktera (engl. typographical characters). Ali, ti znakovi odgovaraju i kao oznaka za nešto drugo. Oni su i "doslovni, tj. bez preciziranog konteksta" (Boldrini 2002: 202). Boldrini uzima te znakove kao primjer jezičkih elemenata koji se fluidno kreću kroz Danteove slojeve značenja:

U svakom slučaju, od čitaoca se traži da odvoji slova - tipografske znakove - od "stvarnih", "personificiranih" znakova te različita otjelovljenja tih znakova/karaktera jedno od drugog; u prvom slučaju moramo identificirati slova na doslovnom nivou i "utjelovljenja" na alegorijskom, dok u drugom slučaju moramo uraditi obrnuto. Zaplićemo se u dvostruko obrtanje, gdje doslovno postaje alegorijsko, a alegorijsko doslovno. (prevela L. M.; Boldrini 2002: 202$)^{8}$

${ }^{8}$ Izvorni tekst: "In either case, the reader seems to be asked to separate the letters - typographical characters - from the 'actual' 'personified' characters, and different embodiments of the characters from each other; in the first option proposed, we would have to 
U ovom poglavlju već sam govorila o tome da je kontekst samog teksta Finnegans Wake krovni kontekst u kom obitava njegov književni jezik - tome dodajem tezu L. Boldrini da se taj književni jezik, tj. njegovi elementi fluidno kreću kroz denotativna/konotativna značenja i da tekst u sebi mijenja odnose između Danteova četiri sloja značenja i tako ostvaruje totalnu (totalizirajuću?) polisemiju.

Šta znači ta promjena odnosa slojeva značenja? Boldrini navodi dvije mogućnosti: a) tipografski znakovi/karakteri su doslovni sloj, a svi likovi koje označavaju su alegorijski sloj i b) svaki lik/mjesto/predmet postoji na doslovnom nivou tek kad je imenovan, dok drugi likovi/mjesta/predmeti, kojima tipografski znakovi/karakteri odgovaraju, ali ih ne predstavljaju (npr. ukoliko se pojave slova $\mathrm{H} \mathrm{C} \mathrm{i} \mathrm{E} \mathrm{kao} \mathrm{početna} \mathrm{slova} \mathrm{triju} \mathrm{riječi} \mathrm{koja}$ odgovaraju kontekstu tih riječi, a nisu referenca na lik HCE), postoje na alegorijskom nivou.

U oba slučaja čitalac treba razlikovati doslovna slova i slova upotrijebljena u određenom kontekstu. Teorija o četiri sloja značenja ne otkriva strukturu koju Finnegans Wake uključuje u svoj semiotički sistem - ta je teorija samo korisna okvirna mapa. Za Dantea je doslovni sloj onaj u kom su sadržani ostali nivoi značenja. Međutim, kod Joycea ta značenja idu u različitim smjerovima, te njihovi slojevi postaju stranci jedni drugima. Pred kraj svog teksta Boldrini navodi misao J. Mazzea: "kod Joycea bi ono što je skriveno moglo biti i sámo slovo". Drugim riječima, ono što je skriveno mogla bi biti i sama mogućnost skrivanja, tj. to bi mogao biti sam kôd koji inače služi da se neko značenje sakrije.

Ako se osvrnemo na Boldrininu teoriju, pogotovo na mogućnost b, primjetno je da ona pretpostavlja da postoje "tipografski znakovi/karakteri koji odgovaraju likovima, ali ih ne predstavljaju". Stoga ti znakovi prema ključu uspostavljenog koda odgovaraju nekom "liku", ali u datoj su rečenici lišeni konteksta tog ključa kako bi se vratili na svoj doslovni nivo, kako bi se lišili ključa (pa H, C i E više nisu tipografski znakovi/karakteri lika Earwickera, već su to doslovce slova $\mathrm{H}, \mathrm{C}$ i E). Sta taj mehanizam radi književnim likovima? Upravo ono što je sadržano u Boldrininoj mogućnosti b: uobičajeno je da ime književnog lika bude alegorija koja omogućava liku da bude doslovan u radnji teksta; u slučaju Finnegans Wake ime (tj. niz slova koji više ne funk-

identify the letters with the literal level and the 'embodiments' with the allegorical, while in the second, we may have to do just the reverse. We seem to be getting entangled in a double reversal where the literal becomes allegory and the allegory becomes literal - where each element moves fluidly between levels of signification." 
cionira kao pravo ime) postaje doslovno, dok sam "lik" postaje alegorijski. Utoliko se mijenja ontološki status lika unutar radnje teksta - njegovo ime egzistira u kontekstu iz kog je izbačen - dakle lik prestaje biti imenovan u pravom smislu, njegovo ime ga je napustilo, napustila ga je jezička oznaka koja ga inače uprisućuje i, štaviše, omogućava mu egzistenciju. Utoliko, on se više ne može nazvati "književnim likom" kakav književnost do Joyceove poetike poznaje.

McCarthyjev protagonist priča o gubitku i pokušaju obnove svog sjećanja, a njegova ličnost trebala bi pomoću alegorijskog potencijala fragmenata sjećanja izaći na vidjelo i učiniti ga prisutnim u doslovnom sloju radnje romana. Međutim, junak Remaindera eksplicitno odbija razumjeti svoja sjećanja, dakle odbija njihov alegorijski potencijal i ponavlja ih kako bi dokazao njihovu doslovnost. Uslijed toga, sjećanja ne poprimaju status alegorije, već postaju doslovna, a sam protagonist ostaje izvan doslovnog sloja radnje.

$68 \quad \mathrm{U}$ djelu Lots of Fun at Finnegans Wake Fordham analizira treće poglavlje treće knjige Finnegans Wake, u kom Issy promatra svoj odraz u ogledalu i u toj konkretnoj sceni stvara svoju dvojnicu: "Da li ona ima dvoboj sa sobom u ukazanju sa samom sobom (...)?” (prevela L. M.; Joyce 2012: 528) ${ }^{9}$ - Fordham objašnjava tu rečenicu kao Issynu predigru za samo-ljubav, kao Issynu ljubav prema njenoj projekciji. Pojam "projekcije" nije posebno definisao, već ga jednostavno izjednačio sa odrazom u ogledalu - tako će u nastavku ovog poglavlja projekcija biti korištena u smislu odraza, slike originala. U poglavlju o Issy nije jasno da li je projekcija u ogledalu odraz Issynih želja njena idealna slika svog sopstva. Fordham napominje da je Issyna projekcija u biti slika Issy u očima muškaraca, posebno u očima njenog oca Earwickera. Stoga se pojam projekcije ne vezuje za ličnu perspektivu osobe koja je projicirana. Naime, Fordham sve likove određuje kao projekcije: sna H. C. Earwickera, naratorovog sna, vizija drugih likova unutar tog naratorovog sna ili pak Joyceovih snovitih vizija.

\footnotetext{
${ }^{9}$ Izvorni tekst: "is she having an ambidual act herself in apparition with herself (...)?" Objašnjenje prijevoda (korišten je Oxford English-Bosnian Student's Dictionary, 2010): "imati dvoboj sa sobom"/“dvoboriti se"/"dvostrano se boriti" kao prijevod "have an ambidual act yourself"; ambi-dual kao "ambi" = dvojak, dvostran i "dual" kao varijacija "duel" = dvoboj.
} 
Taj Fordhamov pojam projekcije može se povezati sa Boldrininim odnosom doslovnog i alegorijskog značenja teksta. Književni likovi pojavljuju se u sklopu sna (koji je prema Levinu doslovni sloj značenja teksta), oni su sada zapravo projekcije tog sna, projekcije doslovnog značenja teksta. Međutim, likovi o kojima govori Fordham su likovi koje obuhvata Boldrinina mogućnost b: to su ujedno i likovi koji su imenovani u tekstu (pa su doslovni) i likovi kojima određeni tipografski znakovi odgovaraju, ali ih ne predstavljaju (pa su alegorični).

Jednostavno rečeno, književni lik u Finnegans Wake ograničen je na sanjanu verziju sebe (ne znamo kakav je taj lik izvan sna). ${ }^{10} \mathrm{U}$ tom snu lik je ili imenovan (pa ulazi u doslovni sloj značenja, jer znamo da je to ime oznaka za taj lik) ili su određena slova alegorija za taj lik (primjer sa Here Comes Everybody, gdje H C i E funkcionišu dvojako, i kao tipografski znakovi lika i kao "obična" slova). Stoga, ako kažemo da je lik projekcija sna, to znači da je u Finnegans Wake doslovnost književnog lika njegova sanjana verzija. Lik je projekcija priče (sna), a sama priča nije projekcija lika. Lik čini priču doslovnom, a priča ne čini lik doslovnim, već je ona alegorija za taj lik. Priča ga ne može učiniti doslovnim jer je ona zapravo san koji je, kao i uvijek, alegorija. Lik se doslovno pojavljuje u priči (o tome govori Boldrini) kada je imenovan, ali ta doslovnost lika samo je autorefleksija priče, priča se reflektira na sanjanu verziju lika od koje je nastala (isto se dešava sa likom kada je alegorijski imenovan). Lik se ne gradi kako priča teče, ${ }^{11}$ on je projekcija, statična slika priče koja se sada poigrava tom statičnošću i u toj igri nastaje kôd te priče.

Objašnjenje naravi sna i pojma projekcije može nam reći nešto više o Joyceovim "književnim likovima", kao i o McCarthyjevom protagonistu. Razmotrimo citat: "Narcisisi su poput kćerki inverzije. Esila kroz svoje časove smijeha postaju prijateljski odrazi u kasnijem životu" (prevela L. M.; Joyce 2012: 526). ${ }^{12}$ Issy je ovdje uspoređena sa Narcisom i sa Alisom

${ }^{10} \mathrm{Na}$ ovo upućuje i Norris u četvrtom poglavlju The Decentered Universe of Finnegans Wake, naslovljenom "The Ontological Condition", str. 73-97.

${ }^{11}$ Prema tome, ne može izgraditi svoj identitet. Tim stavom referiram na Ricoeurovo Sopstvo kao drugi, na poglavlje o sopstvu i narativnom identitetu (Ricoeur 1992: 140-169): narativ gradi identitet lika, dakle njegov/njen narativni identitet, i to radi gradeći identitet same priče. Dakle, identitet priče konstituiše identitet lika.

12 Izvorni tekst: "Nircississies are as the doaters of inversion. Secilas through their laughing classes becoming poolermates in laker life." Ovaj prijevod zahtijeva nešto duže objašnjenje. Napominjem da su sva denotativna značenja riječi preuzeta iz Oxford English-Bosnian Student's Dicitonary (izdanje iz 2010. godine). Dakle: 
iz Alise sa druge strane ogledala, koji u svojim odrazima nalaze prijatelje i s njima provode ostatak ("laker" kao "later") života u jezeru ("laker" kao "lake"). Narcisova zagledanost u svoj vlastiti odraz nastaje, kako napominje McLuhan u Razumijevanju medija, radi stanja "samoamputacije" (pojam su izvorno skovali H. Seyle i A. Jonas): "Mladićev lik je samoamputacija ili produžetak izazvan podražajnim pritiscima. Kao sredstvo protupodražaja, taj lik stvara neodređenu otupjelost ili šok koji uskraćuje prepoznavanje. Samoamputacija sprečava samoprepoznavanje" (McLuhan 2008: 41-42). Issyna projekcija u ogledalu zaleđena je slika Narcisa u jezeru, projekcija je samoamputacija, slika koja njegov sluh čini otupjelim na dozivanja nimfe Eho. Tu sliku Issy koristim da bih poentirala priču o likovima u Finnegans Wake. Naime, ti "likovi" su projekcije sna, utoliko oni ne postoje izvan sna, jedina doslovnost koja im je dostupna jeste doslovnost njihove sanjane verzije. Pošto su projekcije, oni nisu narativni identitet koji se razvija kroz priču u koju su smješteni - priča ih ne projicira, već sama nastavlja da se razvija čineći od likova kao svojih projekcija kôd. Budući da su projekcije, likovi su poput Narcisovog odraza u jezeru, poput Alise koja je ušla u svijet iza ogledala. Shodno mitu o Narcisu, likovi ne čuju nimfu Eho, a ta se okolnost $70 \mathrm{u}$ mitu podudara sa nedostatkom autentičnog diskursa likova u Finnegans Wake. McCarthyjev protagonist ostvaruje vezu sa Narcisom kroz mehaniku samoamputacije: on ne prepoznaje sebe u svom vlastitom sjećanju, štaviše, on želi da to sjećanje ponavlja stalno, da ono vječno traje. Odraz njegovog lika u jezeru vredniji mu je od njega samog.

\section{OKLOP OD TINTE}

Fordham (Lots of Fun at Finnegans Wake) posvećuje dosta pažnje sceni u sedmom poglavlju prve knjige Finnegans Wake, u kojoj Shem ispisuje histo-

\footnotetext{
"Nircississies" = kombinacija "Narcissus" i "Issy", također aluzija na žargonizam "sissy" = kukavica, sestrica;

"doaters" = fonološki slično "daughters", ali i u značenju "doat" = piljevina, pa su kćeri shvaćene kao ostaci, otpaci cjeline, majke;

"Secilas through their laughing classes" = prema A Reader's Guide to Finnegans Wake (1996: 269), "Secilas" je "Alices" napisano "u ogledalu" (stoga Alise = Esila), a cijela fraza aludira na "Alice through the looking glass". Nisam u prijevod "laughing classes" uključila tu aluziju; "poolermates" = prema Ethical foyce (2002: 131) ta fraza znači "prijatelj u lokvi”, tj. aluzija na Narcisov odraz u jezeru;

"laker" = fonološki slično "later", sa aluzijom na "lake", opet u kontekstu Narcisa.
} 
riju svijeta na svome tijelu - tako njegova koža postaje podloga za pisanje i njegovo tijelo istovremeno trune od tolike količine tinte:

(...) alšemičar je pisao po svakom kvadratnom inču jedinog tabaka hartije koji mu je preostao, svom sopstvenom telu, dok njegovom korozivnom sublimacijom ljuštura jednog nesvršenog sadašnjeg vremena nije polako odmotala celokupnu veselozvučnu ćudljivoukalupljenu kružnokotrljajuću istoriju (...) (Džojs 2014: 188)

Najbitnija u tom poglavlju jeste Fordhamova teza o odnosu umjetnika i njegovog djela (Fordham 2007: 51-53). Fordham zaključuje kako iz tog poglavlja proističe da "pisanje nije refleksija svijeta, već oklop kojim se pisac brani od svijeta. To je oklop od tinte".

Scena u kojoj nastaje Shemov "oklop od tinte" može itekako poslužiti ovom radu jer komentira i mimetički potencijal književnosti, koji se suprotstavlja tezi (koju Fordham spominje) da je književnost "refleksija svijeta". Oklop od tinte u ovom slučaju skriva tijelo umjetnika i funkcionira kao enkripcija tog tijela. Tintom ispisan tekst oblikuje se prema tom tijelu koje je istovremeno "ukaljano" tintom, enkripcija mijenja izvornik prema kom je nastala i skriva njegovo značenje u njihovom jedinstvu. Tintu Shem pravi od svojih tjelesnih tekućina i fekalija, ona dolazi iz njegove nutrine, ona je ista materija od koje je sazdano tijelo, samo eksternalizovana i u funkciji oklopa. Ta scena u sedmom poglavlju poslužila mi je da ilustrujem ranije spomenutu tezu o izloženosti koda. Enkripcija je u Finnegans Wake utoliko taj crni oklop od tinte, koji je namjerno izložen svijetu, ali nije njegova upadljiva refleksija, već je upravo usmjeren ka formi koju prati, ka formi umjetnikovog tijela koje skriva. Kôd prkosi svojom izloženošću zato što zna da ga njegov ključ neće poništiti - utoliko je Shemov oklop sazdan od tinte koju je njegovo tijelo upilo. Ključ enkripcije referira i na tijelo i na oklop, i na izvornik i na kôd koji je od njega nastao i u njega se ponovno upio.

Oklop od tinte može se povezati i sa tezom R. Lachmann u knjizi Phantasia/Memoria/Rethorica. Lachmann u poglavlju "Mnemotehnika i simulakrum" govori o tezi Leonarda da Vincija da su knjige "tijela bez duše" i nastoji je protumačiti kroz vezu književnosti sa pamćenjem (Lachmann 2002: 184-189). Lachmann tumači knjigu kao nositelja pamćenja koje se može naslijediti jedino preko materije - pamćenje se materijalizira fizičkim utiskivanjem tinte u papir i ukoričenjem papira u knjigu. Knjiga je utoliko tijelo bez duše, tj. njena nepobitna materijalnost, a upravo činjenica da je ona puki objekt daje mogućnost pamćenju da se iz nje svakim novim čitanjem apstrahira. Na taj način knjiga se dematerijalizira i oživljava pamćenje. 
"Tijelo bez duše" također je i protagonist romana Remainder. Tokom romana on nastoji materijalizirati ono za što tvrdi da su fragmenti njegovog sjećanja. On bi čak mogao krivotvoriti vlastito sjećanje. Štaviše, sigurna sam da tome i teži. Ta težnja očituje se u činjenici da želi u nedogled ponavljati te materijalizacije svojih uspomena, a da ih pritom ne razumije. On uživa u materijalizaciji, a ne u dematerijalizaciji. Stoga je svaka njegova radnja zapravo usmjerena ka ispisivanju oklopa od tinte. Kraj romana i trag koji avion ostavlja za sobom sugerišu da protagonist ne želi da se zna gdje je započeo ispisivanje kalupa - on želi da njegov kalup bude savršen i vječan, svrha i vrijednost po sebi.

Pred kraj spomenutog poglavlja o mnemotehnici Lachmann napominje: "ko se sjeća svih stvari zaboravlja poredak svijeta". Ta rečenica može se primijeniti i na Joyceov i na McCarthyjev tekst, još važnije, na samu definiciju koda koju sam dala u uvodu. Dakle, ako je kôd prelazak iz mimetičkog u smisaoni registar, a Joyceovi i McCarthyevi "likovi" nastoje isprazniti sebe od sjećanja i uroniti u zaborav sačinjen od oklopa od tinte, onda ti "likovi" nestaju pod kodom, koji ostaje u mimetičkom registru. Pritom, tinta je ona "koja se sjeća svih stvari", ona je Shemova "kružnokotrljajuća istorija". Ta historija ostaje u mimetičkom registru i stoga "zaboravlja poredak svijeta" taj zaborav znači napuštanje smisaonog registra, napuštanje ideje umjetnosti kao "refleksije svijeta" i vječni ostanak u polju enkripcije. Staviše, Lachmann definira zaborav kao situaciju u kojoj se "nešto više ne može prepoznati kao pripadno određenom znakovnom kontekstu" - a to nešto skriveno je oklopom od tinte, totalizirajućim kodom.

\section{ZAKLJUČAK}

Pojam double talk (što se može prevesti kao "udvostručeni govor") specifičan je za Finnegans Wake, a označava "fenomen kada jedan niz riječi kod čitatelja potakne asocijaciju koja uzrokuje da drugi niz riječi paralelno teče" (Norris 1976: 101). U double talk su riječi koje bi uzrokovale psihičku napetost cenzurisane "manje opasnim" riječima. Tome bih dodala da se radi o autocenzuri - sam tekst Finnegans Wake sebe cenzuriše i time cenzura proširuje inicijalno značenje izvornog (necenzurisanog) teksta. Double talk zapravo je istovjetan fluidnosti slojeva značenja koje je objasnila Boldrini: tipografski znak funkcioniše kao alegorija za lik (prvi asocijativni niz), ali i kao doslovna sekvenca slova, neovisna o liku (drugi asocijativni niz). Ime H. 
C. E. "cenzurisano" je frazom "Here Comes Everybody" koja istovremeno referira i na lik H. C. E. i na Everymana, dakle ime H. C. E. vrši autocenzuru i proširuje značenjsko polje.

Sada napokon dolazim do drugog pojma koji sam navela u naslovu rada. Raslojavanje jezika se u kontekstu Finnegans Wake razvija kao postupak stvaranja dvaju ili više nizova asocijacija: oba niza koriste se riječima/znakovima konkretno upisanim u tekst i oba ostvaruju legitimnu značenjsku poveznicu sa tim jedinstvenim nizom označitelja.

Metodom double talk i stvaranjem "nestvarnih" asocijacija raslojava se sam književni tekst, čime on izlaže svoju kodiranu prirodu čitatelju. U kontekstu romana Remainder double talk ostvaren je nizom "nestvarnih" asocijacija za kojima protagonist traga - McCarthyjev junak želi ostati unutar teritorije takvih asocijacija, za koje mi pretpostavljamo da imaju stvarnu referencu na njegova sjećanja mada on nigdje ne tvrdi da je tako (podsjećam: on ne želi shvatiti, on želi beskonačno ponavljati).

Shodno tome, u slučaju Joyceovog i McCarthyjevog djela kôd teksta ne teži smisaonom registru, on se zadržava u svojoj podražavalačkoj aktivnosti. Joyce u biti parodira imenovanje i karakterizaciju likova tipografskim znakovima/karakterima. McCarthyjev protagonist, odričući se sjećanja, ne dopušta da mu se identitet gradi skupa s pričom. Joyce i McCarthy tako svode svoje književne karaktere upravo na znakove, vraćajući eventualnu vjerovatnost (smisaonu vrijednost) koju su upisali u lik ka kodu (mimetička vrijednost) kojim je ta vjerovatnost izgrađena.

Čin imenovanja lika zapravo uključuje u sebe performativ, dakle iskaz koji mijenja stanje stvari u realnom, fizičkom svijetu. Stoga je moja završna misao o fiktivnim likovima, kao i o književnom tekstu uopće, misao da bi oni mogli biti jedan vid performativa. U tekstu U. Eca "On the ontology of fictional characters" autor si postavlja pitanje: "Zašto plačemo zbog smrti Anne Karenine?” - i zaključuje da ne plačemo jer je Tolstoj napisao da je Anna umrla, već zato što je ona umrla. Prema tome, tekst o Anni Kareninoj i sama Anna kao književni lik uzrokuju reakciju, promjenu (konkretno, plač) u stvarnom svijetu - taj tekst fukcioniše kao performativ i to postiže ostvarenom vjerovatnošću. Dakle, likovi su nezavisni od fikcionalnih tekstova u kojima se pojavljuju, na što upućuje i činjenica da misli o liku nisu misli o njegovom autoru.

No, to nije slučaj sa Joyceom - mislim da je ono što čini Finnegans Wake "nečitljivim" upravo činjenica da on parodira tu moguću performativnost, dakle mogući utjecaj na vantekstualni svijet. McCarthy, jednako tako, stvara protagonistu kom je ideal sjećanje kao izolirana cjelina, ne kao događaj 
koji se desio u stvarnom svijetu stvarnim ljudima. To sam već nagovijestila u poglavlju o oklopu od tinte. Joyceov tekst eksplicira kôd koji koristi da bi podražavao vantekstualni svijet - time on skreće pažnju na sebe kao na "refleksiju svijeta" i umjesto da kôd otvori ka materijalnom svijetu, ka procesu dekodiranja, koji bi tekst učinio vjerovatnim i time ga uveo u smisaoni registar, on usmjerava svoj tekst, svoj oklop od tinte, nazad ka umjetniku kog štiti. Na taj način njegov književni tekst želi opstati kao tekstualni kôd u vantekstualnom svijetu.

Opstanak tekstualnog kôda u vantekstualnom svijetu u konačnici je teži poduhvat nego što se pretpostavlja. To možemo vidjeti na primjeru McCarthyjevog Remaindera. U tom romanu sproveden je isti sistem građenja i izlaganja koda kao u Finnegans Wake, s tim što ulogu građenja i izlaganja preuzima glavni junak (a u Finnegans Wake to čini sam tekst). To je i razlog zašto Remainder opstaje kao roman, a Finnegans Wake izlazi iz tog žanrovskog okvira. Remainder nema ekspliciranu autoreferencijalnost kao Joyceov tekst, pri čemu sve protagonistove pripovijesti o njegovom životu namjerno nisu dokazane kao autorefleksija, već ostaju u polju "nestvarnih" asocijacija.

Dakle, opstati kao tekstualni kôd u vantekstualnom svijetu teško je i to se vidi na primjeru McCarthyjevog protagoniste: i sam čitatelj neosnovano pretpostavlja da je svaka junakova inscenacija nekog događaja (kao što je opetovano postavljanje crnih mačaka na crveni krov) zapravo kodirani oblik neke njegove uspomene, trag njegove prošlosti. Problem nastaje kada drugi likovi u romanu, time i sam čitatelj, shvate da te inscenacije nemaju pretenziju na dekodiranje, već da su kôd koji uživa u samom sebi. To čak nije kôd koji teži pronalasku smisla u samom sebi, to je kôd koji uživa u svojoj mimetičkoj aktivnosti i koji je želi vječito ponavljati. Odjednom, junakove inscenacije u Remainderu postaju potencijalno nasilne prema stvarnosti - one upravo odbijaju mijenjati išta u toj stvarnosti iako im je ona omogućila da uopće postanu stvarne. Na sličan način su Joyceovi likovi u Finnegans Wake "nasilni" - oni prijete konvencionalnoj slici ljudske ličnosti, slici kakvu inače generira književni tekst tokom svog puta ka vjerovatnosti.

\section{LITERATURA}

Bahtin, M. 1989. O romanu. Sa ruskog preveo Aleksandar Badnjarević. Beograd: Nolit. Barthes, R. 2002. S/Z. Oxford: Blackwell Publishing.

Beckett, S. i dr. 1929. Exagmination Round his Factifications for Incamination of Work in Progress. London: Faber and Faber. 
Biti, V. 2000. Pojmovnik suvremene književne i kulturne teorije. Zagreb: Matica hrvatska. Boldrini, L. 2002. Let Dante Be Silent: Finnegans Wake and the Medieval Theory of Polysemy. Internet. 31. 5. 2017.

Burell, H. 1996. Narrative Design in Finnegans Wake: The Wake Lock Picked. Gainesville: University Press of Florida.

Derrida, J. 2007. Pisanje i razlika. Sa francuskog prevela Vanda Mikšić. Sarajevo: Šahinpašić.

Džojs, Dž. 2014. Finegana buđenje. Sa engleskog preveo Siniša Stojaković. Beograd: Pasus. Eco, U. 2009. "On the ontology of fictional characters: A semiotic approach". U: Sign Systems Studies 37: 82-97.

Fordham, F. 2007. Lots of Fun at Finnegans Wake. New York: Oxford University Press Inc.

Gomes, H. F. 2014. "Building and Disintegrating Stories". U: A fournal of Anglo-American Studies II (3): 1-17.

Joyce, J. 2012. Finnegans Wake. Hertfordshire: Wordsworth Editions Limited.

Kerol, L. 2016. Alisa u zemlji čuda / Alisa sa druge strane ogledala. Sa engleskog preveo Konstantin Popović. Beograd: Kontrast.

Lachmann, R. 2002. Phantasia/Memoria/Rhetorica. Zagreb: Matica hrvatska.

Lukács, G. 1990. Teorija romana : jedan filozofskobistorijski pokušaj o formama velike epske literature. Sa njemačkog preveo Kasim Prohić. Sarajevo: "Veselin Masleša"/Svjetlost.

McCarthy, T. 2007. Remainder. London: Alma Books.

McCreedy, J. Narrating Sigla: The 'Battle Diagram' and Structuring Finnegans Wake, Chapter One. Internet. 31. 5. 2017.

McLuhan, M. 2008. Razumijevanje medija: mediji kao čovjekovi produžeci. 3. izd. Sa engleskog preveli David Prpa i Nada Zgrabljić Rotar. Zagreb: Golden marketing - Tehnička knjiga.

Miller, S. 2015. "Intentional Fallacies: (Re)enacting the Accidental in Tom McCarthy's 'Remainder"”. U: Contemporary Literature LVI: 634-659.

Norris, M. 1976. The Decentered Universe of Finnegans Wake: a structuralist analysis. Baltimore/London: The Johns Hopkins University Press.

Riffaterre, M. 1978. Semiotics of Poetry. Bloomington: Indiana University Press.

Riffaterre, Michael. 1973. "The Self-Sufficient Text". U: Diacritics, vol. 3, no. 3: 39-45. Internet. 29. 5. 2018.

Watt, I. 2000. The Rise of the Novel. London: Pimlico.

\section{Abstract}

\section{JOYCE'S FINNEGANS WAKE AND MCCARTHY'S REMAINDER: CODING AND LANGUAGE STRATIFICATION}

The purpose of this paper is to consider the terms "code" and "language stratification" by analysing James Joyce's Finnegans Wake and Tom McCarthy's Remainder. A code is considered to be a transition from mimesis to meaning. The starting point of the analysis is the genre of Finnegans Wake and Remainder, and the state of fictional 
characters in these literary works. The paper argues that the fictional characters have a "rhetorically encrypted identity", and furthermore considers methods with which this identity develops, and their consequences. The paper also shows how the technique of bricolage is used in Finnegans Wake and Remainder, and explains the connection between bricolage and encryption. The last part of the analyses explains the way in which Joyce's and McCarthy's texts use their literary language to self-reflect about the code the texts are written in. The code thus stays within the area of mimesis (and does not proceed to the area of meaning). This text also proposes the idea of a literary text as performative, which consequently changes the ontology of fictional characters in their respective literary works.

Keywords: generative fiction, code, memory, bricolage, performative 